\title{
Ecocatastrophe Caused by Artificial Fertilizers can and should be Prevented
}

\author{
Chikov VI*, Akhtyamova G A and Batasheva S N \\ Department of sciences, Kazan Institute of Biochemistry and Biophysics, Russia
}

Submission: April 03,2018; Published: April 30, 2018

"Corresponding author: Chikov VI, Department of sciences, Kazan Institute of Biochemistry and Biophysics, Russia, Email: vichikov@bk.ru

\section{Introduction}

According to The World Ocean Atlas 2013 the world faces the increasing tendency of growing low-oxygen zones in the oceans (Figure 1) [1]. They are caused by nitrogen-phosphate fertilizers input to the rivers flows and further into the ocean. This results in rapid algae bloom - the food for oxygen-consuming bacteria. Low-oxygen zones are spreading throughout the world. The marine life could not be supported in such dead zones.

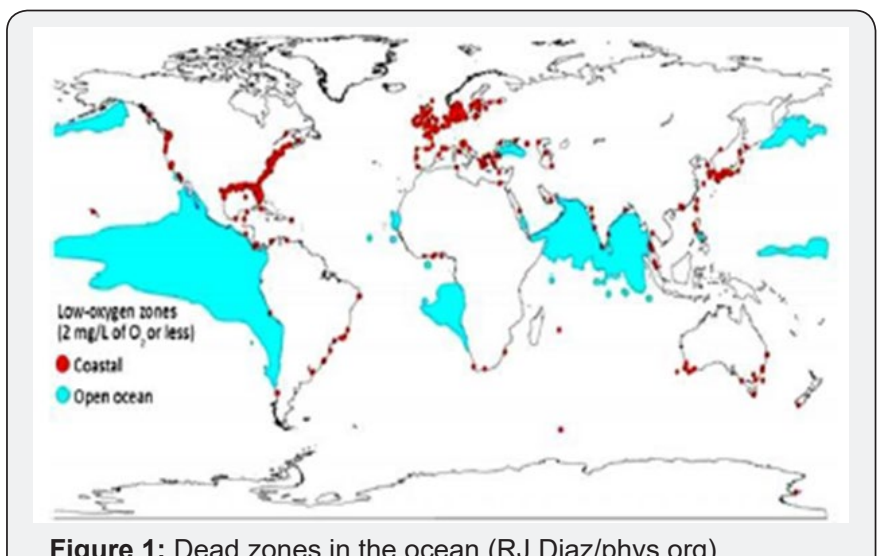

Figure 1: Dead zones in the ocean (RJ Diaz/phys.org).

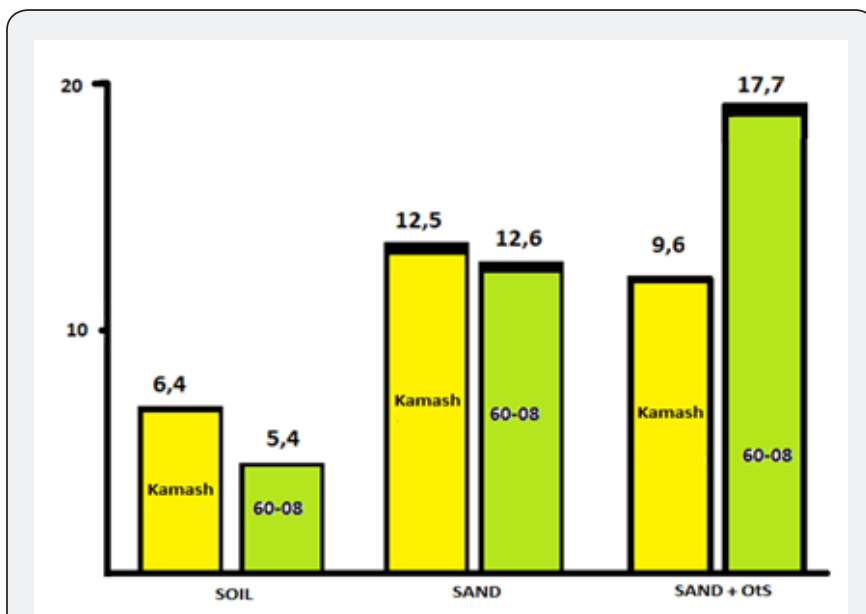

Figure 2: The mass of roots before the tillering resistant (Kamashevsky)and non-resistant (60-08) barley cultivated in soil, sand, and in sand after treatment with ammonium compounds (outflow stimulant - OtS).
Figure 1 Our research of root formation with different drought-hardiness barely has revealed the importance of primary roots development in early stage of ontogenesis, which enables them to reach water going deep into the soil. It is true that intensive crops with higher mineral status have smaller roots as compared to their uncultivated predecessors. The significance of mineral status for roots formation has been tested in special experiments. Cultivation of plants under controlled conditions in washed sand, as compared to soil, doubles the dry mass of roots with both types of barley (Figure 2). This effect could be increased with intensive crops subject to additional spraying of leaves with a solution of (10-4M) ammonium compounds (OtS), which suppress the activity of apoplastic invertase, and increase sucrose export from leaves [2].

Other annual plants have showed similar response of the roots growth to spraying with ammonium compounds. Outflow of sugars to the roots, increased by OtS, has been accompanied by the increased nitrogen fixation, compared with the amount of fertilizers applied before sowing [3].

The accumulated long-term data on the regulation of photosynthetic carbon metabolism when changing donoracceptor relations between photosynthesizing and consuming organs and the level of nitrogen nutrition [4] make it possible to explain the stimulation of root formation by characteristics of composition of the final product of photosynthesis under the said conditions. Since the decreasing nitrate concentration makes photosynthesis more carbohydrate, the plant faces a problem of utilizing the sugars formed during photosynthesis. It has been proven [4] that a fully-grown leaf can use no more than $5-7 \%$ of generated photosynthetic products. At the same time, new growth of apical points and shoots (the main consumers of photosynthetic products) is impossible in the absence of nitrogen. Under these conditions, the sugars formed during photosynthesis can be used only for the synthesis of polysaccharides. Such a polysaccharide, being a final product of photosynthesis, can be represented only by cellulose and only in cells that have high percentage of cellulose in their total dry mass (i.e. highly vacuolated). Such cells (growing by extension) can only be in the roots [5]. 
It turned out that to develop the effect of root growth stimulation one should sow the seeds in a sowing furrow (with a cross section of $5 \times 5 \mathrm{~cm}$ ) filled with sand, with soil beneath [6]. This means that in order to increase the mass of water-conducting roots, nitrate concentration near the seed should be reduced. This will increase their drought resistance, and symbiosis of the plant with nitrogen-consuming microorganisms will compensate for considerable part of the nitrogenous fertilizer applied before sowing.

Therefore it is suggested to change agricultural technology of crops growing as follows: Firstly, reduce the amount of the applied artificial fertilizers, secondly, separate the flows of the seeds and fertilizers during sowing, and thirdly, apply less fertilizers between the rows of the sowed seeds. All this will allow to get the following benefits as compared to the old agricultural technology:

a. Saving of mineral fertilizers applied into the soil, since more than half of them are washed out by rainwater and aggravate environmental situation.

b. Increasing of drought resistance in highly productive varieties of cultivated plants sensitive to drought. Drought resistance will increase with development of waterconducting roots.

c. Increase of natural fertility of cultivated soil with the increase of amount of post-harvest organic substances in soil in the form of the roots residue. d. The implementation of this agricultural technology is also an important way to reduce $\mathrm{CO}_{2}$ in the atmosphere. Estimates suggest [7] that increase of airborne $\mathrm{CO}_{2}$

e. Concentration over the last 100 years is equivalent to decrease of soil organic matters.

\section{References}

1. Chikov VI, Bakirova G G, Batasheva SN, Sergeeva AA (2006) The influence of ammoniates on ${ }^{14} \mathrm{CO}_{2}$ assimilation in flax. Biologia Plantarum. 50(4): 749-751.

2. Chikov VI, Avvakumova N Iu, Bakirova G G, Belova L A, Kulakov A A (2002) Possibilities of controlling photosynthesis and plant productivity by affecting the extracellular space of a leaf Modern problems of agriculture. Kaliningrad pp. 156-162.

3. ChikovVI (2017) The Participation of Apoplast Invertase in the Regulation of Photosynthesis by Stomatal Mechanism. Journal of Plant Sciences 5(5): 134-145.

4. Keerberg O F (1975) Photoregulation of plant metabolism and morphogenesis. Nauka, Moscow, Russia, pp. 158-170.

5. Dobrovolskyi GV, Nikitin ED (1990) Soil functions in the biosphere and ecosystems. Nauka, Moscow, Russia.

6. Chikov VI, Akhtyamova G A, Batasheva S N, Diurbin D S, Tagirov M S H, et al. (2017) Rooting in early stages of ontogenesis of different barley morphobiotype. Niva Tatarstana 3(4): 50-52.
Your next submission with Juniper Publishers will reach you the below assets

- Quality Editorial service

- Swift Peer Review

- Reprints availability

- E-prints Service

- Manuscript Podcast for convenient understanding

- Global attainment for your research

- Manuscript accessibility in different formats

( Pdf, E-pub, Full Text, Audio)

- Unceasing customer service

Track the below URL for one-step submission https://juniperpublishers.com/online-submission.php 